Cezary J. OLBROMSKI

Katolicki Uniwersytet Lubelski

\title{
Kilka uwag na temat normatywności w teorii polityki: perspektywa utopii politycznej
}

\begin{abstract}
„Prawda wyuczona trzyma się nas jak przysztukowana proteza kończyny [...], natomiast prawda, której dorobiliśmy się dzięki własnemu myśleniu, jest jak naturalna kończyna: tylko ona rzeczywiście do nas przynależy".
\end{abstract}

Arthur Schopenhauer ${ }^{1}$

\section{Wstęp}

W Spółczesny wymiar polityczności opiera się na skuteczności działania politycznego. Jest to sfera coraz bardziej sprofesjonalizowanego działania, które ma sprostać współczesnej coraz bardziej ograniczonej polityczności. Nasza ocena tego, co otrzymujemy w agendzie dnia ogranicza nasz dyskurs do ewaluacji ilościowej działalności polityków, ogranicza także poziom partycypacji politycznej obywateli. Turbulencje cywilizacyjne ( $c f$. Greenspan) wymuszają coraz dokładniejsze planowanie i przewidywanie, lecz - paradoksalnie - przyczyniają się do skrócenia perspektywy czasowej działania i planowania działania politycznego. Współczesny poziom teorii gier decyzyjnych jako praktycznych narzędzi pozwala na coraz bardziej wyrafinowane planowanie coraz większej liczby możliwych scenariuszy. Czy państwo staje się „fabryką” kierowaną przez elity pozbawione polityczności ${ }^{2}$ ? Moim zdaniem odpowiedź na to pytanie powinna być negatywna.

1 A. Schopenhauer, O myśleniu z siebie samego, „Logos i Ethos” 1992, nr 2, s. 139.

2 Cf. C. Schmitt, Teologia polityczna i inne pisma, Społeczny Instytut Wydawniczy ZNAK, Kraków 2000, passim. 


\section{Skuteczność cnotą polityczną?}

Klasyczna doktryna greckiej polis obecna w europejskiej doktrynie politycznej mniej więcej od trzech stuleci ustępuje miejsca perspektywie idealnotypologicznego homunculusa. Dzieje się tak z powodu odrzucenia horyzontu paidei i zastapienia go polityczną taktyką skutecznego wygrywania wyborów oraz wpisywania się w przypadkowe kompetencje urzędów-beneficjów.

Zrelatywizowanie zasad życia politycznego polega wówczas na sprowadzeniu rezultatów działania politycznego do skuteczności wyalienowanego narzędzia wyborczego, przestaje zaś być sposobem weryfikacji kompetencji politycznych ( $c f$. Leo Strauss). Przy zastosowaniu takiej optyki miarą kompetencji polityka jest sama, pozbawiona kontekstu uzasadnienia normatywnego, skuteczność ${ }^{4}$. Innymi słowy, skuteczność nie tylko staje się pewnym minimum koniecznym do wyznaczenia sfery obowiązywalności kompetencji polityka, dzięki któremu polityk uwierzytelnia swoje polityczne kwalifikacje, ale wydaje się być jedynym kryterium przydatności politycznej. Od czasów starożytnych skuteczność polityczna stanowiła bardzo ważne aczkolwiek wstępne kryterium przy doborze osób na ważne stanowiska w państwie. Skuteczność rozumiana jako efektywność działań oraz prawdopodobieństwo wystapienia zamierzonego skutku narzuca katalog wartości i norm, które nie są tworzone w zaciszu politycznych gabinetów. Jest ona zdolnością do wyznaczania prawa do posiadania mandatu zaufania dla męża stanu, nie może więc być kryterium ewaluacyjnym ex post. Znaczenie nadawane skuteczności działań politycznych nie powinno więc być czymś absolutnym, bowiem kryteria skuteczności działań absolutne nie są. Umiejętność określenia celów pozostaje w ścisłej relacji z możliwością ich realizacji. Teoretycznie rzecz biorąc, każdy cel poza samą skutecznością jako celem uzasadnia wartość znaczenia polityki.

Nie jest w pierwszym rzędzie winą polityków, iż ograniczają się do działań motywowanych przez skuteczność i jej pochodne, mimo że poru-

3 Pisałem o tym niedawno w innym miejscu, tak więc zbieżność treści obu tekstów jest niemal nieunikniona. Cf. C. J. Olbromski, Teoretyczne i praktyczne ograniczenia implementacji zasad demokratycznych modelu deliberatywnego $w$ Europie Środkowej na przełomie XX $i$ XXI w. - uwagi in statu nascendi, „Środkowoeuropejskie Studia Polityczne" 2009, nr 1-2, s. 37-50.

4 Cf. L. Strauss, Sokratejskie pytania, Fundacja Aletheia, Warszawa 1998, passim. 
szają się oni w ramach coraz bardziej sprofesjonalizowanego działania, które ma sprostać współczesnej coraz bardziej ograniczonej polityczności. Nie ponoszą oni również odpowiedzialności za coraz większy udział czynników pozapolitycznych w sferze decyzji politycznych. Od pewnego czasu korzystam z następującej ilustracji ${ }^{5}$. W jednym z europejskich miasteczek wprowadzono nowy system regulacji ruchu drogowego w miejsce dwóch starych systemów: systemu sygnalizacji świetlnej - regulującego ruch miejski oraz systemu radarowego - kontrolującego prędkość uczestników ruchu drogowego. System sygnalizacji świetlnej połączono z systemem radarowym $\mathrm{w}$ taki sposób, iż w sytuacji przekroczenia przez kierowcę prędkości zmienia się światło na czerwone albo światło czerwone pozostaje, jeżeli w momencie przekroczenia prędkości paliło się, zmuszając tym samym kierowcę do zatrzymania się. Dwa niezależnie od siebie działające systemy zakładające ingerencję w zachowania uczestników ruchu miejskiego połączono w jeden, również zakładający ingerencję. Różnica jakościowa jest kolosalna bowiem od przestrzegania przepisów dotyczących dopuszczonych prędkości w ruchu miejskim uzależniono w ogóle możliwość przemieszczania się w ruchu miejskim, tym samym w sposób drastyczny ograniczone zostało prawo do niezdominowanego poruszania się po mieście. Przykład ten ilustruje, iż jakość sfery polityczności jest określona przez stopień identyfikacji podmiotu z miejscem swojej działalności. Pozorna izolacja działań polega na identyfikacji z pewną przestrzenią.

\section{Ewaluacja odpowiedzi na sytuację polityczną}

Brak jest tutaj tego, co określić można strategią kreowania sytuacji politycznej przez odwołanie się , do wpływania na...”. W takiej sytuacji skuteczność działania wydaje się być cnotą, umiejętnością wyznaczania celów adekwatnych do możliwości politycznej ekspresji, którą określę jako minimalizowanie tego, co podnieść może ryzyko niepowodzenia działania politycznego. Stosowanie tej strategii oznacza ograniczenie podejmowanych działań do tego, co skuteczne nie zaś tego, co trafne ze względu na dalekosiężne cele, ale naznaczone ryzykiem. Procedury, indykatory i ewaluacja zamiast tego, co pochodzi spoza samego kontekstu

5 Cf. www.onet.pl. 
uzasadnienia normatywnego dotychczasowego działania politycznego - katalogu indykatorów i wyznaczników ilościowych. Od deliberatywnych uzgodnień na płaszczyźnie moralnej - a zatem pozapolitycznej - zależy sprawne funkcjonowanie państwa demokratycznego. Instrumentalne zapisy niskiego kontekstu podlegają kwalifikacji moralnej obywateli. Demokracja wydaje się więc być porządkiem społecznym przyjętym wtórnie przez szukających konsensusu w sferze moralnej obywateli. Aktualna pozostaje teza Platona, iż państwo ma troszczyć się nie tylko o ilościowe, ekonomiczne (dobrobyt) wskaźniki, lecz również kultywować cnoty i skłaniać obywateli do zachowań w ramach sfery arete. Nie chodzi jednak o totalność porządku politycznej moralności cnoty, ale o demokrację wartości.

\section{Po pierwsze polityczność, po drugie demokracja, po przecie prawa czlowieka}

Dyskusja na temat demokracji przypomina smakowanie impresjonistycznego obrazu. Gdy patrzymy nań z bliska widzimy tylko nieuporządkowanie różnokolorowych plam farby, rozpoznajemy poszczególne pociagnięcia pędzlem, widzimy, iż farba jest chropowata, kładziona w różnych kierunkach, trójwymiarowa. W miarę oddalania się od płótna powierzchnia obrazu staje się coraz bardziej płaska, równocześnie widzimy coraz więcej, rozpoznajemy postaci, przedmioty, krajobrazy, plamy układają się w nową jakość figur, figury tworzą perspektywę. Ten kto smakuje obraz odkrywa zamysł artysty, przywołuje z pamięci własne figury, symbole, kolory. Odchodząc jeszcze dalej widzi już tylko ramy. Demokracja jest właśnie takim impresjonistycznym dziełem sztuki, z tą wszakże różnicą, iż nie sposób zobaczyć całego obrazu. Pomimo świadomości istnienia ram niepodobna stwierdzić ich obecność.

Posługuję się tym porównaniem jeszcze z jednego powodu, mianowicie chcę pokazać różnicę między antycznym greckim i nowożytnym podejściem do demokracji. Platoński mit jaskini i smakowanie impresjonistycznego dzieła to dwa różne jakościowo podejścia. Powrót do jaskini i odejście od obrazu to dwa kierunki prowadzące do dwóch różnych oglądów. Pierwszy zakłada ontologiczną wizję ładu politycznego, na przykład demokracji, który nie potrzebuje praw człowieka jako odrębnego katalogu twierdzeń, ponieważ wywodzone one są z tego samego poziomu ontologicznego co polityczność określająca ramy obywatelskości, 
drugi zaś w empiryczno-analitycznym ujęciu racjonalizmu nowożytnego zakłada ułomność natury ludzkiej i niewystarczalność perspektywy ontologicznej polityczności jako w sposób zupełny ujętej relacji egzystowania pospołu. Prawa człowieka pojawiają się dopiero wówczas, gdy zagrożone są prawa obywatela, prawa człowieka osadzone zostają w nowożytnym instrumentalnym racjonalizmie i wykraczają znacznie poza demokratyczny porządek ustrojowy. Piekło jest dla tych, którzy przeżyli niebo na ziemi ${ }^{6}$, prawa człowieka są narzędziem w walce o godność obywatela, dyskusja na temat praw człowieka jest koniecznością bowiem nowożytny model demokracji nie zasad potrzebuje a skuteczności w ich egzekwowaniu.

\section{Deus ex machina współczesnej polityki}

Gdy Platon pisze, iż nie ma - w państwie idealnym - takiej funkcji, którą można byłoby obsadzić kierując się kryterium płci, lecz kryterium ducha to - z normatywnego punktu widzenia zamkniętego systemu swoistej ontologii społecznej - nie jest już potrzebny dodatkowy komentarz. Nawet biorąc pod uwagę nieprzystawalność ówczesnego kontekstu kulturowego tej wypowiedzi (np. ówczesna rola kobiet w społeczeństwie) do dzisiejszych realiów nie musimy zastanawiać się czy Platon miał rację, czy jej nie miał. Wypowiedź ta - weryfikowana w obrębie określonej ontologii politycznej - nie wymaga zewnętrznego uzasadnienia. Stosując podejście empiryczno-analityczne nie sposób na takiej konstatacji poprzestać. Przywołując zaś Platona nie sposób nie podziwiać aktualności tego zdania wywiedzionego przecież z przesłanek teoretycznych, których źródłem była nie tyle polityczna rzeczywistość Aten czy Sparty, lecz konsekwentnie stosowana metoda/zasada drugiego żeglowania.

Znaczenie modelu normatywnego polega na tym, iż rozwiązuje on wiele problemów - nie tylko teoretycznych - na długo przed ich pojawieniem się czy zdiagnozowaniem w ramach podejścia empiryczno-teoretycznego. W sferze polityczności myślenie dedukcyjne i utopijne trudne są do rozdzielenia. Polityczność jest przedmiotem rozumu, a ten nadaje jej szczególną wartość poznawczą - normatywnie ujęta polityczność uznaje realność wszystkich sfer bytowych (cf. Voegelin) także realność transcendentalnej sfery, której nie sposób sprowadzić do sfer niższych.

${ }^{6}$ Zdanie autorstwa jednego ze współczesnych krakowskich filozofów, niestety nie jestem w stanie ustalić nazwiska. 
Rzeczywistości transcendentalnej nie sprowadzimy do niższego kontekstu uzasadnienia empirycznego nie tylko ze względu na brak narzędzi. Ontologiczne powody takiego ,sztywnego" stanowiska są oczywiste: wartości nie są stopniowalne.

\section{Tolerancja jako minimum socjalne rozumienia}

Kolejnym problemem związanym z normatywnością działań jest zakres obowiązywalności katalogu pojęć normatywnych. W skrajnych teoriach normatywnych starego typu ( $c f$. Beyme) ontologiczne założenia grawitowały w stronę metafizyki. Pojęcie prawdy obiektywnej grało pierwsze skrzypce zawłaszczając sferę, która genetycznie rzecz ujmując, należeć powinna do sfery empirycznej weryfikowalności hipotez. Problemy metodologiczne sztywnego stanowiska teoretycznego przekładają się na niemożność konkluzywnego ujęcia przypadków jednostkowych. Z drugiej jednak strony wyniki analitycznego i empirycznego podejścia ferowanego przez teoretyków neopozytywistycznych prowadzi li tylko do deskrypcji sfery polityczności. Przenosząc ujęcie teoretyczne obecne w teorii polityki na sferę zjawisk społecznych stwierdzić można, iż normatywne ujęcie idei społecznych prowadzi postulatywnie do rozumienia podstaw konkretnego nurtu, idei, zaś ujęcie analityczne empiryczne odwołuje się do pojęcia tolerancji wyznaczając zasadę równości różnych idei i nurtów. Podstawą takiego podejścia jest nie tyle przejęcie się ideami tolerancji ile zawieszenie sądu na temat prawdziwości ze względu na brak odpowiednich narzędzi pojęciowych. Tolerancja nie jest więc programowym podejściem zakładającym ważność wielu stanowisk mieszczących się w jakimś przedziale obowiązywalności - na marginesie należy stwierdzić, że wyznaczenie takiego przedziału zakładałoby już podejście normatywne - lecz przyjęciem a priori za konkluzywne każdego fenomenu społecznego, politycznego na mocy jego faktyczności. To, co zdarza się ma rację, ponieważ zaistniało. Takie podejście prowadzić będzie do konieczności uporządkowania ontologicznego wszystkiego, co się pojawiło, a to znowu wymaga podejścia normatywnego.

Klaus von Beyme szansy na uzdrowienie sytuacji metodologicznej upatruje $\mathrm{w}$ topice ${ }^{7}$. Wedle tego stanowiska wyjście od jednostkowego

${ }^{7}$ Cf. K. von Beyme, Wspótczesne teorie polityczne, s. 42-43. 
przypadku bądź problemu i dedukcyjne wywodzenie na jego podstawie pozytywistycznego podejścia do sfery polityczności jest skutecznym antidotum na abstakcyjno-spekulatywne podejście tych normatywistów, których działalność naukowa sprowadza się li tylko do tworzenia spekulatywnych modeli opartych na postulatywnej wartości systemu jako wewnętrznej spójności logicznej. Nie jest to jednak argument przekonujący. Po drugiej wojnie światowej - dzisiaj ta tendencja jest także widoczna - budowano teorie polityki w oparciu o obudowywanie fenomenów społecznych pojęciami teoretycznymi. Takim fenomenem skutecznie konkurującym o miano pojęcia-klucza było pojęcie demokracji ${ }^{8}$. Dzisiaj takim pojęciem zdaje się być pojęcie praw człowieka, wokół którego narasta nie tylko obszerna literatura przedmiotu - co zrozumiałe - ale także literatura, wedle której pojęcie praw człowieka jest pojęciem centralnym teorii polityki. Nie są to przypadki odosobnione. W historii idei taką funkcję pełniły pojęcia zaczerpnięte z systemów politycznych, teorii ekonomicznych, filozofii. Redukcja procesów politycznych do zmiennych, które są rezultatem procesów politycznych wymusza nieustanną zmianę odtwórczego eksplikowania stanowiska teoretycznego. Uzgadnianie stanowisk teoretycznych z określonymi empirycznie zjawiskami i procesami politycznymi polega w tym przypadku na wyabstrahowaniu tego, co potwierdza zasadniczą ważność przyjętego ze względu na określoną zmienną. Jednakże postulowana wartość normatywności w falsyfikacji teorii politycznych polega na znaczeniu określonej zmiennej jako czynnika korygującego przedział obowiązywalności jakiegoś twierdzenia. Posłużę się w tym momencie przywołanym wyżej przykładem różnicy w adekwatności opisu rozumienia fenomenu politycznego i przyjęcia jego znaczenia jako zmiennej korygującej a przyjęciem jego deskrypcji i wpisaniem jej w sferę rozważań teoretycznych li tylko na mocy pewności istnienia w sferze polityczności. Korygowanie teoretycznego ujęcia tym będzie się różnić od rozszerzenia empirycznego opisu zjawiska, że to pierwsze zakłada otwartość systemu teoretycznego, dla którego kryterium i warunkiem koherencji jest logiczna - także empiryczna - weryfikowalność twierdzeń nie zaś enumeratywnie osiagana pewność występowania jakiegoś zjawiska. Fakt występowania jakiegoś zjawiska jako pozostającego w relacji z innymi zjawiskami należy udowodnić, nie zaś wpisywać jako indukcyjnie dowodliwy materiał empiryczny. Żaden ze słynnych normatywistów ( $c f$. Platon, Machiavelli,

${ }^{8}$ Cf. K. von Beyme, Wspótczesne teorie polityczne, s. 43. 
Voegelin, Strauss) nie negował dowodowej wartości danych empirycznych. Negowali oni wszakże wartość istnienia danych empirycznych jako dowodu absolutnego, w znaczeniu wyemancypowania spod wpływu systemu politycznego. Platońska teoria polityki nie była rewersem tablicy reguł i wzorów geometrycznych, lecz miejscem empirycznej weryfikacji ważności twierdzeń metodą dorównującą ścisłością tej, której rezultatem były reguły i wzory.

W kontekście normatywności powrócę do zagadnienia skuteczności w działaniu politycznym. Analizując pozycję obywatela państwa obywatelskiego określić można pewne minimum socjalne określone na poziomie zgodnym z pewną statystyczną regularnością stylu życia. W podobny sposób przez określenie sfery aktywności obywatelskiej wyznaczyć można pozostającą w dyspozycji obywatela przestrzeń moralnego wyboru. Inaczej rzecz przedstawia się w przypadku działalności politycznej podejmowanej przez wyłonionych reprezentantów. Normatywny wymiar działania politycznego wymaga wyraźnego określenia zasad ewaluacji. Obowiązują dwa sposoby określenia tych zasad. Po pierwsze, ewaluacja działań polityków ze względu na efekt. Po drugie, ewaluacja działań polityków ze względu na założone cele, przy założeniu realizacji efektu praktycznego jako drogi do przyjętego celu. Podział ten jest w jakimś sensie pochodną wyróżnionych przez M. Webera dwóch typów działania racjonalnego zorientowanego bądź na cele, bądź na wartości. Jednakże z punktu widzenia Weberowskiej analizy działań społecznych zarówno działania zorientowane na cel i korzystające $\mathrm{z}$ tego powodu z określonego przyczynowo-skutkowego kontekstu, jak i działania zorientowane na wartości, w jednakowy sposób uwolnione są od błędu doboru adekwatnych środków działania w drodze indukcji. Czy będzie to przyczynowo-skutkowy kontekst dowodzenia potrzeby odniesienia do wartości w działaniu społecznym, czy też wyizolowanie motywów wymuszone zawężeniem kontekstu uzasadnienia podjętych działań do określonego efektu naocznie uchwytnego zawsze w centrum uwagi pozostanie adekwatność metody w relacji do celu/efektu. Będą to zatem odniesienia do wartości albo ważne ze względu na warunkowanie innych sytuacji o kardynalnym znaczeniu ewaluacyjnym w kontekście wartości konstytutywnych dla zadanego/zaplanowanego do realizacji celu?

Interpretacja i ewaluacja działań w sferze polityczności to - nawiązując do Webera - odnajdywanie analogii między doświadczeniami psychicz-

9 Cf. M. Weber, Sens ,, wolnej od wartościowań” socjologii i ekonomii, s. 141 i n. 
nymi jednostek a sferą racjonalności działań. Analityczne i empiryczne ujęcie sfery polityczności wydaje się więc być archetypem ujęcia szukającego sensu w odniesieniu do wartościującej ewaluacji. Wyznaczanie poziomu korzyści aktualnej w danej perspektywie czasowej - prawdopodobieństwo efektu - jest więc archetypem trwałości dyspozycji do realizacji wartości doraźnej, jakim jest określony cel. Wymiar „teraz” przyjmuje pozycję dominująca, ponieważ realizacja efektu jako celu ostatecznego działania - oczekiwanie przez audytorium efektu - wymusza krótką perspektywę czasową. Natomiast wymiar działania politycznego poprzez realizację wartości polega na niezmiennym, bo określonym przez ontologiczny desygnat, odnoszeniu efektu działania do wartości zasadniczej; ów proces nie wymaga żadnej perspektywy czasowej. Innymi słowy, permanentne odniesienie do wartości nie dopuszcza perspektywy czasowej obcej ze swej natury działaniu politycznemu. Jesteśmy wszakże świadomi, iż permanentne odnoszenie do wartości sensu podejmowanych przez wąską grupę działań prowadzić będzie wprost do kryzysu politycznego w każdym systemie politycznym.

\section{Ze statystycznego punktu widzenia bocian jest szary}

Ani deskryptywne ujęcie starające się nadać walor naukowości polityzującym ideologiom dawnych totalitaryzmów intelektualnych, ani analityczne ujęcie zracjonalizowanych instrumentalnie - postmodernistycznych często - ujęć ładu politycznego na Zachodzie nie były na tyle mocnym impulsem, aby traktowane być mogły jako przyczyny powrotu normatywnego podejścia w teorii polityki. Raczej negacja tych dwóch przyczyniła się do ponownego traktowania człowieka jako obywatela i przez pryzmat obywatelskości budowania teoretycznych podstaw polityki. Nie postmodernistyczny ład wielokulturowego współgłosu, lecz wyraźne rozgraniczenie między obywatelskim i nieobywatelskim uczestnictwem w życiu społecznym wyznaczał przez jakiś czas kierunek rozwoju teorii normatywnych. Użyłem czasu przeszłego, ponieważ wyraźnie regionalny charakter obowiązywalności tych koncepcji zdewaluował się w obliczu globalizacji wartości i wielkiego obszaru, który dawno przestał już być marginesem, zawłaszczonego przez wspólny mianownik sfery polityczności obowiązujący globalnie. Nie jest to jednak statystyczna mediana, ani uniwersalnie skrojona i uśredniona teoria, lecz mająca u swoich podstaw normatywne założenia próba przedefiniowania sfery polityczności do modelowej sytuacji polityczności. 
„Państwo nie ma monopolu na władzę, ale posiada wyłączność na stosowanie przymusu w sytuacjach granicznych”. Te słowa Carla Schmitta nie tracą na aktualności, zmienia się wszakże całkowicie ich kontekst. Państwo przestaje powoli być państwem narodowym w takim znaczeniu, iż coraz większe obszary wypierane są przez globalną strukturę ograniczonej i zuniwersalizowanej, lecz jakże totalnej normatywności. Z jednej więc strony empiryczne badania natrafiają na przeszkodę coraz trudniejszą do pokonania ze względu na rozrastający się obszar badawczy, $\mathrm{z}$ drugiej zaś strony charakter norm w teoriach normatywnych w coraz większym stopniu ogranicza dyskurs polityczny do wymiaru ilościowego $^{10}$. Przywołam w tym miejscu moje przedstawione wyżej rozważania na temat skuteczności jako probierza kwalifikacji polityka. Wola obywateli ujmowana jako wyraz ich normatywnego podejścia zastąpiona zostaje w dużej mierze możliwością jej skutecznego wyrażenia. Kreowanie polityki przez męża stanu wymaga uwzględnienia czynników pozapolitycznych w takim stopniu, iż charyzma nie ma okazji do tego, by się objawić. W takiej sytuacji próba odrodzenia normatywnego podejścia w politologii wydaje się być wysiłkiem podejmowanym pod prąd - jako dyskurs, który zderzyć się musi z empirycznymi analizami realnych zdarzeń.

\section{Podsumowanie}

Idealnotypologiczny homunculus nie daje za wygraną. Skuteczność polityczną sprowadza on do narzędzia wyborczego, zaś skuteczność działania polityka wydaje się emancypować spod wpływu norm. Korzysta $\mathrm{z}$ zasady tolerancji jako minimum socjalnego rozumienia oraz z utopii jako z narzędzia normatywnego wyrazu. Antidotum jest w takiej sytuacji zdemaskowanie funkcji skuteczności politycznej, przywrócenie jej znaczenia ontologicznego jako ważnej z punktu widzenia celów wstępnej

10 Krótkim incydentem intelektualnym odwracającym na moment kierunek przemian zdominowanych przez empiryczny trend obowiązujący powszechnie w teorii polityki była restytucja pojęcia utopii dokonana przez Mannheima. Mannheimowska utopia pełniła funkcję ,dezideologizacji” (cf. Beyme) i przeciwwagi dla realnego utopizmu teoretyków ZSRR. Mannheim, także Adorno, Horkheimer i Marcuse stanowili zobiektywizowany i usankcjonowany na Zachodzie punkt odniesienia dla teoretycznej ekwilibrystyki w służbie interesów politycznych Wschodu. Także pragmatyczne podejście do utopii autorstwa Bella (cf. idem) uzupełnia nurt utopijny. 
weryfikacji kompetencji politycznych oraz wyrażanie idei poprzez pozytywne odniesienie do norm.

Za zasadniczy walor modelu normatywnego uznać należy, iż rozwiązuje on wiele problemów - nie tylko teoretycznych - na długo przed ich pojawieniem się czy zdiagnozowaniem $\mathrm{w}$ ramach podejścia empiryczno-teoretycznego.

Pozostaje już tylko jeden nierozwiązany problem. Czasowa perspektywa efektów działań politycznych atakowana ze strony normatywistów jako ograniczenie, ze strony pragmatystów i empirystów jako zasadnicze odniesienie działań.

\section{Bibliografia}

Beyme K. von [2007], Wspótczesne teorie polityczne, z niem. tłum. J. Łoziński, Wydawnictwo Naukowe SCHOLAR, Warszawa.

Olbromski C. J., Teoretyczne i praktyczne ograniczenia implementacji zasad demokratycznych modelu deliberatywnego w Europie Środkowej na przetomie XX $i$ XXI w. - uwagi in statu nascendi, ,Środkowoeuropejskie Studia Polityczne” 2009, nr $1-2$, s. 37-50.

Schmitt C. [2000], Teologia polityczna i inne pisma, z niem. przeł. M. A. Cichocki, Społeczny Instytut Wydawniczy ZNAK, Kraków.

Schopenhauer A., O myśleniu z siebie samego, z niem. przeł. G. Sowiński, „Logos i Ethos" 1992, nr 2, s. 137-144.

Strauss L. [1998], Sokratejskie pytania, z ang. przeł. P. Maciejko, Fundacja Aletheia, Warszawa.

Weber M. [1985], Sens ,,wolnej od wartościowań" socjologii i ekonomii, z niem. thum. E. Nowakowska-Sołtan, w: Problemy socjologii wiedzy, s. 101-148, Wydawnictwo Naukowe PWN, Warszawa.

\section{Summary}

In the opinion of the author, the current dimension of politicization depends on how efficient political activity is. It constitutes the realm of the increasingly professional activity intended to match the current, increasingly limited politicization. At the same time, the assessment of what we are presented with in an everyday agenda both restricts the discourse to the quantitative evaluation of politicians' activities and limits the level of political participation of citizens. Our turbulent civilization forces us to plan more and more precisely, but at the same time it reduces the temporal perspective of political activity. The author attempts to answer the question of whether the state is becoming a 'factory' managed by the elites that are no longer politicized. In his opinion, the answer to this question should be: no, it isn't. 
